\title{
PHARMACEUTICALLY ACTIVE CELL BIOMASS GROWTH PATTERN UNDER CELL SUSPENSION CULTURE OF COMMIPHORA WIGHTII - A CRITICALLY ENDANGERED MEDICINAL PLANT
}

\author{
Shobha MEHRA ${ }^{1}$, $\underline{\text { Tarun }}^{K_{A N T}}{ }^{*}$ \\ ${ }^{1}$ Genetics and Tree Improvement Division, Arid Forest Research Institute, New Pali Road, \\ Jodhpur 342005 - India \\ *Corresponding author. E-mail: tarunkant@icfre.org
}

\begin{abstract}
One of the medicinal treasures of Indian Ayurveda is Commiphora wightii which is being used for treating many diseases due to the presence of an oleo-gum-resin (guggul gum) that is having a number of secondary metabolites which are bioactive principles for a number of medicinally important ayurvedic preparations. Over-exploitation of the plant for this resin led it to the verge of extinction and need to develop an alternative way to produce this guggul gum has become imperative. The present study was aimed to understand the behaviour and growth pattern of cell suspension culture of $C$. wightii, which can foster the way to produce secondary metabolites from invitro cultures or secondary metabolite rich cell biomass. For this, callus was initiated from immature embryos collected from seed raised mature plants and tissue culture raised mature plants on Gamborg's B5 medium supplemented with $0.5 \mathrm{mg} / \mathrm{l}$ 2,4-dichlorophenoxyacetic acid (2,4-D). Cell suspension culture was established for both the samples in Gamborg's B5 medium with 0.5 mg/l 2,4$\mathrm{D}$ and hormone free medium. Study showed a comparable growth where good growth was observed in medium containing hormone than medium without hormone. In tissue culture raised plants highest biomass was observed on $27^{\text {th }}$ day which is $17.3149 \pm 0.71$ gms in hormone supplemented medium while in hormone free medium highest biomass was obtained on $27^{\text {th }}$ day which is $14.6219 \pm 1.28$ gms. Whereas in seed derived plants highest biomass produced in medium containing hormone was on $27^{\text {th }}$ day that is $14.9060 \pm 0.73$ gms while in hormone free medium highest biomass was obtained on $27^{\text {th }}$ day that is $11.2113 \pm 0.74$ gms.
\end{abstract}

Keywords: cell biomass, Commiphora wightii, fresh weight, growth kinetics, suspension culture.

\section{Introduction}

Commiphora wightii (Arn.) Bhandari (Family Burseraceae) is an important and pharmaceutically valuable medicinal plant of arid and semi-arid regions of the Indian sub continent [URIZAR \& MOORE, 2003; DENG, 2007]. It is commonly known as 'Guggul' due to the presence of an oleo-gum-resin which is composed mainly of alcohols, steroids, diterpenes and sterols [VERMA \& al. 1998] and the main active constituents are guggulsterone E and Z [EL ASHRY \& al. 2003]. Many biochemical studies have been done on chemical composition of this exudate showing presence of guggulsterone I, II, III, V, Z, E and ctadecan-1,2,3,4-tetrol [PATIL \& al. 1972, 1973], Identified guggulsterone E \& Z, guggulsterone-I, myrrhanol-A and myrrhanone-A, guggulsterone-M, dihydro guggulsterone-M, guggulsterol-Y [MESELHY, 2003], Presence of essential oils, myrecene, dimycerene and Polymyrerecene [JAIN \& GUPTA, 2006], Presence of Quinic acid, Citric acid myo-inositol and Glycin in leaves, stem and resin through metabolite profiling [BHATIA \& al. 2018]. 
Due to the presence of these diverse groups of compound C. wightii is used for therapeutic purpose. It is used in treating rheumatoidism and arteriosclerosis [GUJRAL \& al. 1960; SATYAVATI \& al. 1969]. The active constituents of this gum are used for treatment of hyper cholesterolemia, ulcers, obesity etc. [SATYAVATI, 1990], for the treatment of neurological disorders, hypertension and asthma [MAHESHWARI, 2010] and to prevent the progression of cancerous cells [SHISHODIA \& al. 2007]. Antioxidant and cytotoxic activity from ethyl acetate extract of $C$. wightii under in-vitro condition has also been reported [ZHU \& al. 2001]. It has also identified as weight loss agent [KIMURA \& al. 2001] and cholesterol lowering agent [JAIN \& GUPTA, 2006].

The natural population of this plant is declining because of relentless harvesting of resin from wild plants through tapping by local people for economic benefits. Other reasons of its declining population are slow growth and poor germination rate [YADAV \& al. 1999] due to which it has been listed as critically endangered species by IUCN [VED \& al. 2015, e.T31231A50131117]. Other than conventional breeding, biotechnological aspects have been explored by many researchers to conserve this valuable plant. Micropropagation has been achieved for $C$. wightii using different explants like nodal segments [BARVE \& MEHTA, 1993; SONI, 2010; PARMAR \& KANT, 2012], shoot tips, nodes, internodes and leaves [SINGH \& al. 2010], seedling explants [YUSUF \& al. 1999; KANT \& al. 2010] and apical and axillary meristem [BHARDWAJ \& ALIA, 2019]. Somatic embryogenesis in $C$. wightii was achieved by repetitive reciprocal transfer of callus between MS basal medium and MS supplemented with plant growth regulators [KUMAR \& al. 2003]. Studies on in vitro guggulsterone production have been done for the production of these compounds without destructing the natural population of $C$. wightii. Production of guggulsterone in callus culture was reported that has been induced from different explants like leaves, zygotic embryos and stem [MATHUR \& al. 2007a]. Guggulsterone production has also been reported in shake flask and bioreactors [MATHUR \& al. 2007b]. Enhanced guggulsterone production in cultures was observed in the presence of Morphactin and 2iP [TANWAR \& al. 2007], Mesquite Gum and Gum Arabic [DASS \& RAMAWAT, 2009] and growth retardants with fungal elicitors [SUTHAR \& RAMAWAT, 2010].

Production of secondary metabolites in suspension culture is also affected by the growth of cells in liquid medium and therefore it is necessary to understand the growth pattern of cells in culture conditions. Growth kinetics of cells in liquid medium has been studied on many plant species through Packed Cell Volume in Phoenix dactylifera L. suspension culture [AL-KHAYRI, 2012], Fresh weight and cell viability in Scrophularia striata Boiss. suspension culture [ARDESTANI \& al. 2015] and Settled Cell Volume in Sorghum bicolor suspension culture [RAMULIFHO \& al. 2019]. So, the present study was conducted to analyse the growth pattern of $C$. wightii cell suspension culture which can pave the path for obtaining healthy cell biomass and for enhancement of guggulsterone production.

\section{Materials and methods}

\section{Plant material}

Immature fruits were collected from healthy seed-derived plants of $C$. wightii growing at AFRI nursery and from tissue culture raised plants growing at AFRI TC field trial, Jodhpur (grown in vitro as in KANT \& al. 2010). 


\section{Explant preparation}

Immature fruits were soaked in water. The floating fruits were discarded. Only the settled fruits were used as explant source. These were washed with tween 20 followed by bavestein and streptomycin (Himedia) treatment. Finally fruits were surface sterilized with $5 \% \mathrm{NaOCl}$ (Sigma-Aldrich). Embryos were scooped out from immature fruits for inoculation.

\section{Callus induction and establishment}

Embroys were inoculated on Gamborg's B5 medium supplemented with $0.5 \mathrm{mg} / \mathrm{l}$ 2,4-D (Sigma-Aldrich) as reported best concentration for callus induction earlier by our team [PARMAR \& KANT, 2014]. Establishment of callus was done for both the source mother plants separately by regular sub-culturing after every 4 week on same medium. Further, callus was inoculated on semi solid Gamborg's B5 medium without any hormone for induction of embryogenesis [PARMAR \& KANT, 2014].

\section{Establishment of cell suspension cultures}

C. wightii suspension cultures were initiated by inoculating non embryogenic callus ( 1 g per flask) in 100-ml Erlenmeyer flasks containing $30 \mathrm{ml}$ liquid medium. The medium consist of same basal salt concentrations of Gamborg's B5 medium which was used for callus induction but without agar. The cultures were initiated for both the source plants in Gamborg's B5 medium Supplemented with 0.5 mg/l 2,4-D and Gamborg's B5 medium without any hormone. The suspension cultures were incubated on a rotatory shaker (Adolf Kuhner AG LSX SMX 1200) at $120 \mathrm{rpm}$ under 16-hr photoperiod in white fluorescent light and at $25 \pm 2{ }^{\circ} \mathrm{C}$.

\section{Suspension growth pattern analysis}

Cell suspension Culture's growth pattern analysis was done by fresh weight and dry weight methods. Cells were collected from flasks every $3^{\text {rd }}$ day after inoculation on a pre-weighed Whatmann filter paper disc by filtering the suspension culture. Total weight of the filter paper and cells were determined and then weight of the filter paper was subtracted to obtain the fresh weight (FW) of cells. Filter paper containing the cells was placed in an oven at $60{ }^{\circ} \mathrm{C}$ for $24 \mathrm{hrs}$ and weighed at regular intervals until the weight remains constant. Dry weight (DW) was obtained by subtracting weight of paper with dried cells from preweighed paper's weight.

\section{Determination of cell viability}

Viability of cells in suspension culture was checked by Evan's blue staining method. Cells were taken from suspension culture every $3^{\text {rd }}$ day after inoculation and stained with $0.4 \%$ Evan's blue dye (Himedia). Stained cells were observed under microscope (Nikon Optiphot - 2) at 20x magnification.

\section{Results}

\section{Establishment of callus culture}

Callus was initiated from immature embryos for both the source plants and per cent callusing was recorded (Table 1). Tissue culture raised plant's explant showed a little higher percentage than seed derived plant's explant. The non - embryogenic callus converted to embryogenic callus when cultured on Gamborg's B5 medium without any hormone (Figure 1). This showed the progressive growth of embryogenic callus on semi solid medium which can also be induced and established in suspension culture for production for guggulsterones. 
PHARMACEUTICALLY ACTIVE CELL BIOMASS GROWTH PATTERN UNDER CELL ...

Table 1. Initiation of callus on Gamborg's B5 medium supplemented with $0.5 \mathrm{mg} / \mathrm{l}$ 2,4-D.

\begin{tabular}{|c|c|c|c|}
\hline S.No. & Mother plant & \% Callusing & Callus colour and texture \\
\hline 1 & Tissue culture raised plants & 66.66 & Pinkish white, fragile \\
\hline 2 & Seed derived plants & 58.33 & Pinkish white and light brown, fragile \\
\hline & (A) & (B) & (C) \\
\hline & & & \\
& & & \\
\hline
\end{tabular}

Figure 1. Conversion of non - embryogenic callus into embryogenic callus. (A) Induction of callus on Gamborg's B5 medium supplemented with $0.5 \mathrm{mg} / \mathrm{l}$ 2,4-D. (B) Multiplication of callus on same medium. (C) Non-embryogenic callus converting into embryogenic callus on Gamborg's B5 medium without any hormone. (D) Embryogenic callus.

\section{Establishment of cell suspension culture}

Cultures initiated from tissue culture raised plant's explant showed comparatively good growth in medium containing hormone 2,4-D (Figure 2) as compared to cultures in medium without hormone (Figure 3 ) because 2,4-D is responsible for higher rate of cell division. Similar pattern was observed in cultures initiated from seed derived plant's explant (Figures 4, 5). While comparing the two mother plants, tissue culture raised plants gave better response as compare to seed derived plants in terms of having dense biomass which is clearly seen in the flasks.

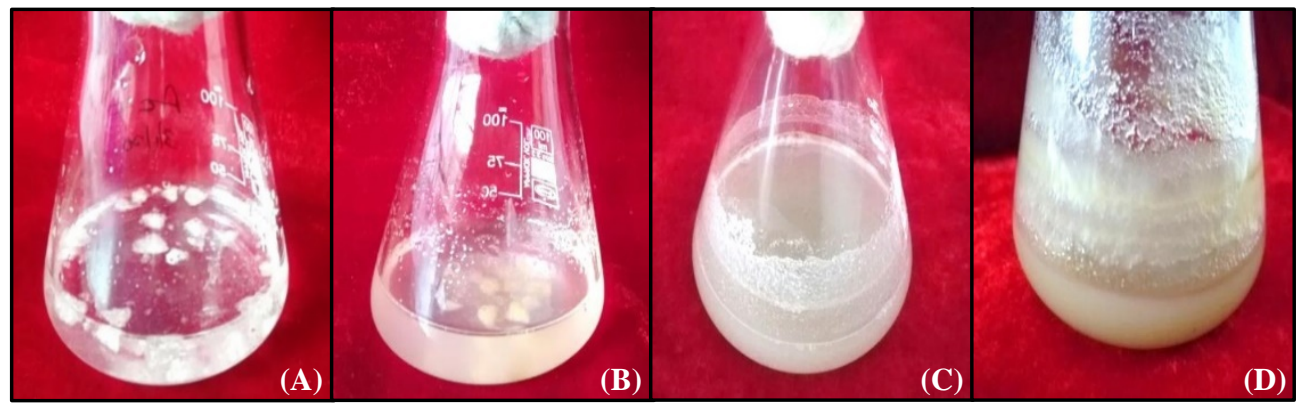

Figure 2. Tissue culture raised plants: Growth pattern of culture suspension in shake flask containing medium with hormone 2,4-D (A-D) A. $1^{\text {st }}$ Day, B. $10^{\text {th }}$ Day, C. $20^{\text {th }}$ Day, D. $30^{\text {th }}$ Day.

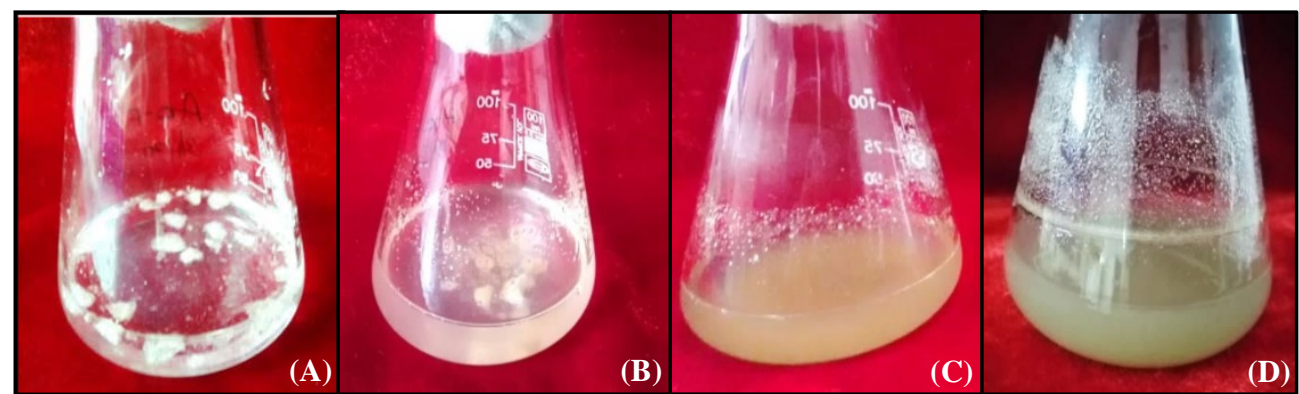

Figure 3. Tissue culture raised plants: Growth pattern of suspension culture in shake flask containing medium without any hormone (A-D) A. $1^{\text {st }}$ day, B. $10^{\text {th }}$ day, C. $20^{\text {th }}$ day, D. $30^{\text {th }}$ day. 


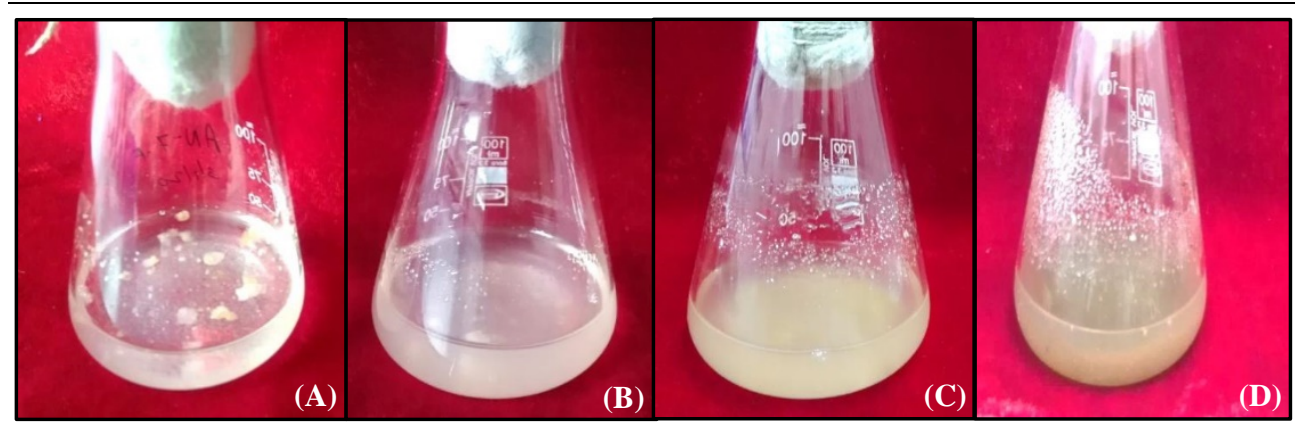

Figure 4. Seed derived plants: Growth pattern of suspension culture in shake flask containing medium with hormone (A-D) A. $1^{\text {st }}$ day, B. $10^{\text {th }}$ day, C. $20^{\text {th }}$ day, D. $30^{\text {th }}$ day.

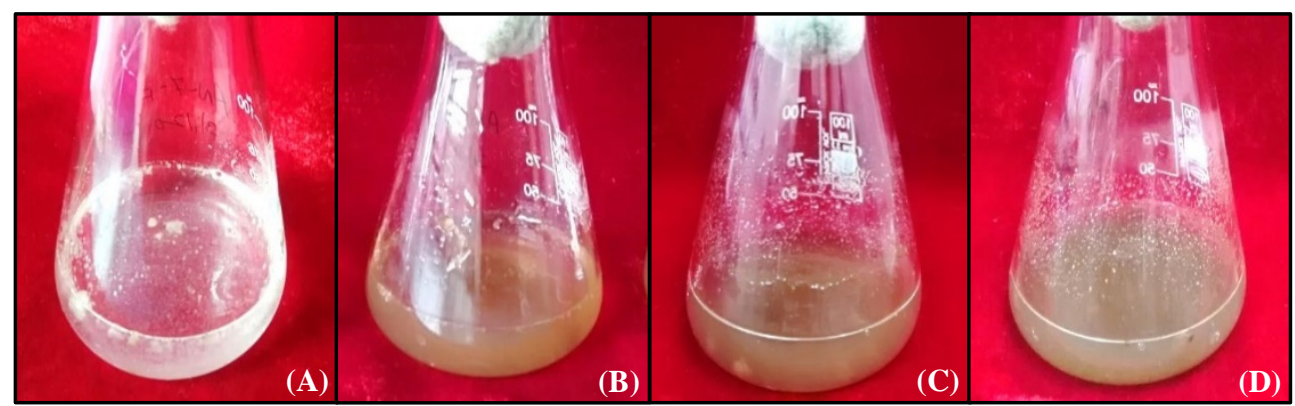

Figure 5. Seed derived plants: Growth pattern of suspension culture in shake flask containing medium without any hormone (A-D) A. $1^{\text {st }}$ day, B. $10^{\text {th }}$ day, C. $20^{\text {th }}$ day, D. $30^{\text {th }}$ day.

\section{Growth pattern analysis of suspension culture}

Tissue culture raised plants: Fresh weight analysis showed that growth of suspension culture in medium containing hormone grew with a short lag phase till day 9 that is the adaptive phase of culture to the new environment. This was followed with exponential growth till $21^{\text {st }}$ day and after that stationary phase was achieved that finally culminated in the death phase marked by apoptosis due to nutrient exhaustion and cellular competition. Similarly suspension culture in medium without hormone showed quite similar growth pattern (Figure 6). Biomass produced was highest in medium containing hormone on $27^{\text {th }}$ day which is $17.3149 \pm 0.71$ gms while in hormone free medium highest biomass was obtained on $27^{\text {th }}$ day which is $14.6219 \pm 1.28$ gms. While comparing the dry weight, results was slightly different with highest dry mass on $18^{\text {th }}$ day in cultures with hormone that is $0.4462 \pm 0.00$ gms and on $24^{\text {th }}$ day in cultures without any hormone that is $0.4336 \pm 0.01$ gms. Growth pattern is shown for both the cultures in Figure 7 .

Seed derived plants: Fresh weight analysis of these cultures exhibit lag phase till $12^{\text {th }}$ day in medium containing hormone $(2,4-\mathrm{D})$ and then grew exponentially till $27^{\text {th }}$ day after that stationary phase was achieved leading to death phase. Similarly suspension culture in medium without hormone showed quite similar growth pattern with a gradual increase in growth with time (Figure 8). Biomass produced was highest in medium containing hormone on $27^{\text {th }}$ day that is $14.9060 \pm 0.73$ gms while in hormone free medium highest biomass was obtained on $27^{\text {th }}$ day that is $11.2113 \pm 0.74$ gms. Dry weight analysis 
PHARMACEUTICALLY ACTIVE CELL BIOMASS GROWTH PATTERN UNDER CELL ...

showed similar results as fresh weight method having highest dry mass on $27^{\text {th }}$ day in medium with hormone that is $0.4325 \pm 0.01$ gms and in medium without hormone highest dry mass was obtained on $27^{\text {th }}$ day that is $0.3899 \pm 0.02$ gms. Growth pattern is shown for both the cultures in Figure 9.

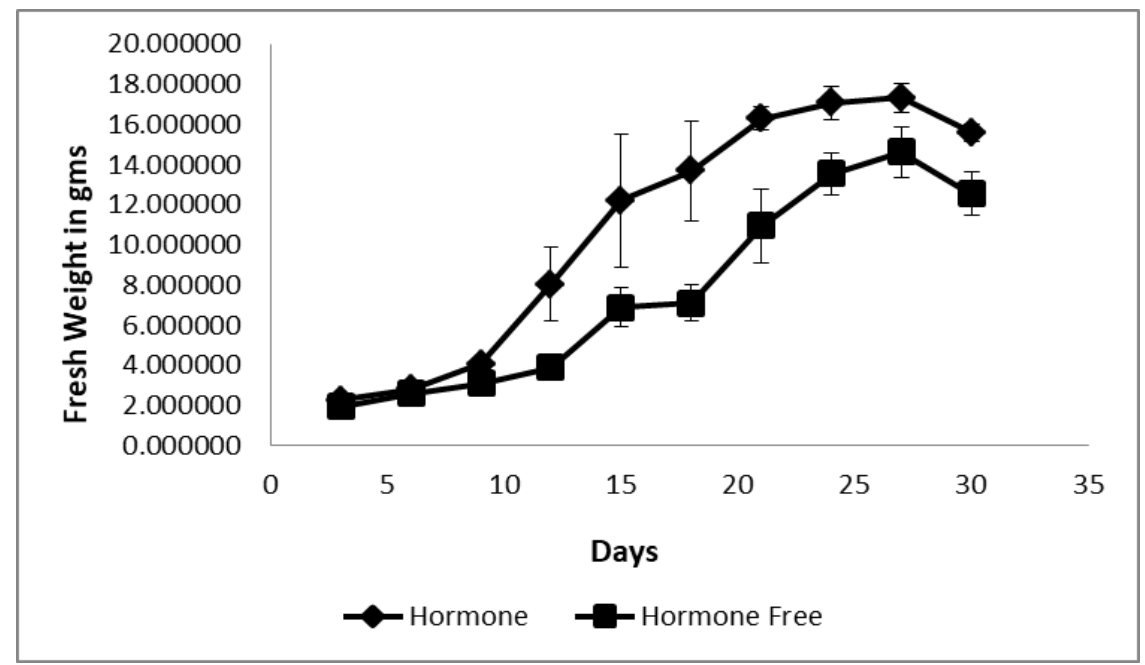

Figure 6. Growth pattern of culture initiated from tissue culture raised plant's explant in media containing hormone and without hormone by fresh weight method.

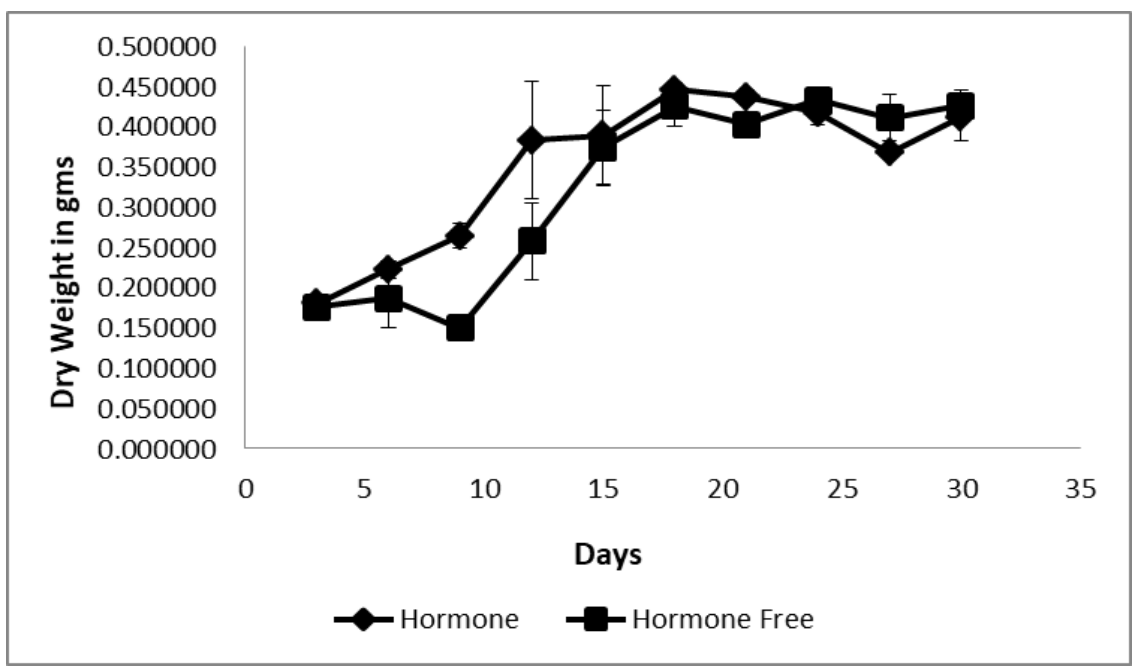

Figure 7. Growth pattern of culture initiated from tissue culture raised plant's explant in media containing hormone and without hormone by dry weight method. 


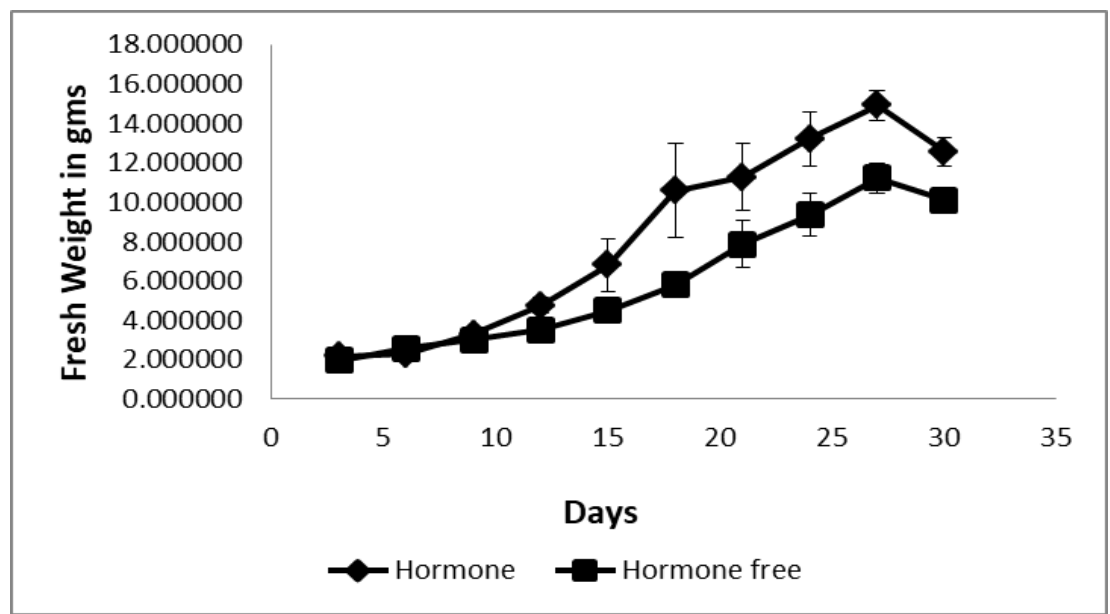

Figure 8. Growth pattern of culture initiated form seed derived plant's explant in media containing hormone and without hormone by fresh weight method.

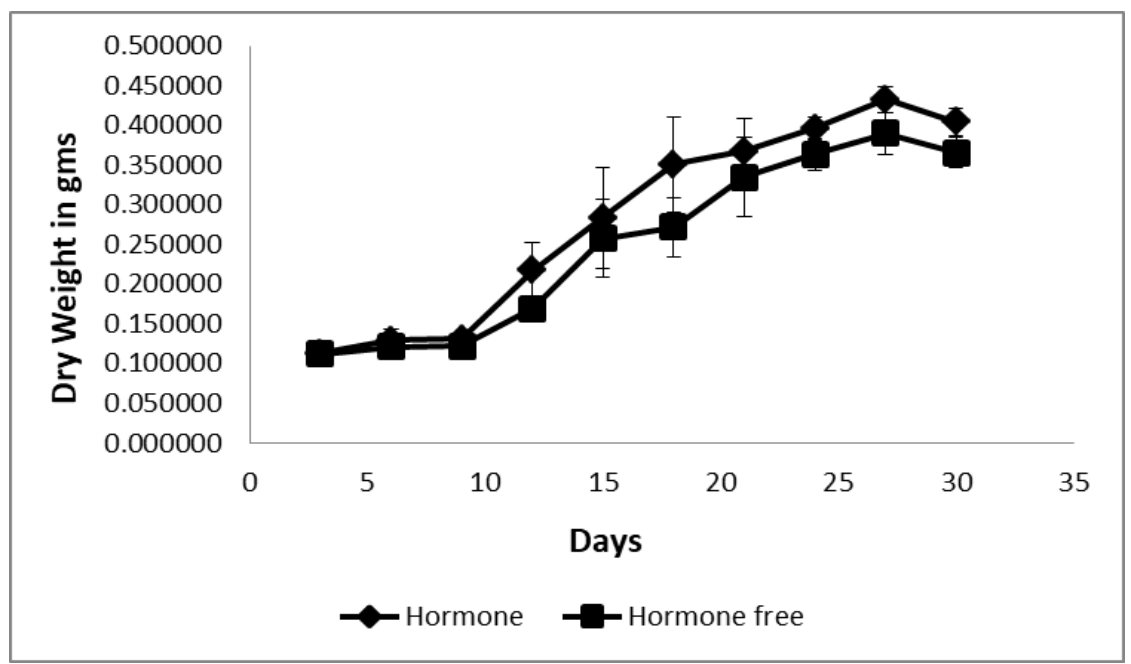

Figure 9. Growth pattern of culture initiated form seed derived plant's explant in media containing hormone and without hormone by dry weight method.

\section{Determination of cell viability}

Evan's blue staining revealed the viability of cells in suspension cultures of seed derived plant. In medium containing hormone a good growth was clearly seen in the culture along with more live cells in exponential phase which then decreased after the initiation of stationary phase (Figure 10). While in medium without any hormone showed slow growth along with less number of cells as compared to medium with hormone (Figure 11). 

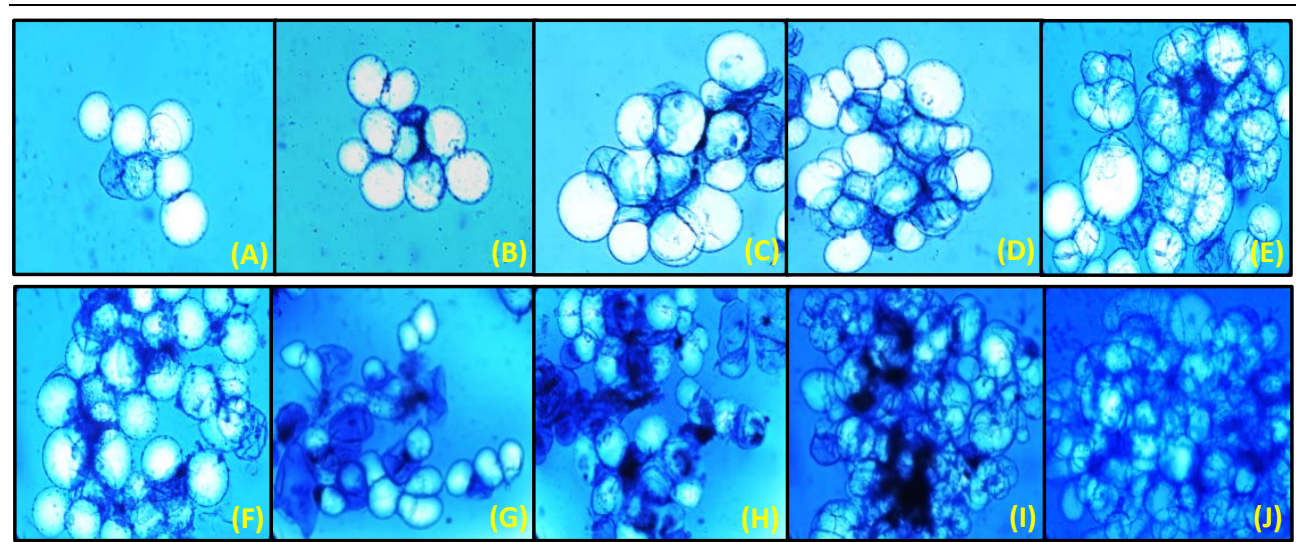

Figure 10. Evan's blue staining of suspension culture in Gamborg's B5 medium containing hormone, that are initiated from seed derived plant's callus showing live and dead cells with the time. (A) $3^{\text {rd }}$ day (B) $6^{\text {th }}$ day (C) $9^{\text {th }}$ day (D) $12^{\text {th }}$ day (E) $15^{\text {th }}$ day (F) $18^{\text {th }}$ day (G) $21^{\text {st }}$ day (H) $24^{\text {th }}$ day (I) $27^{\text {th }}$ day (J) $30^{\text {th }}$ day.
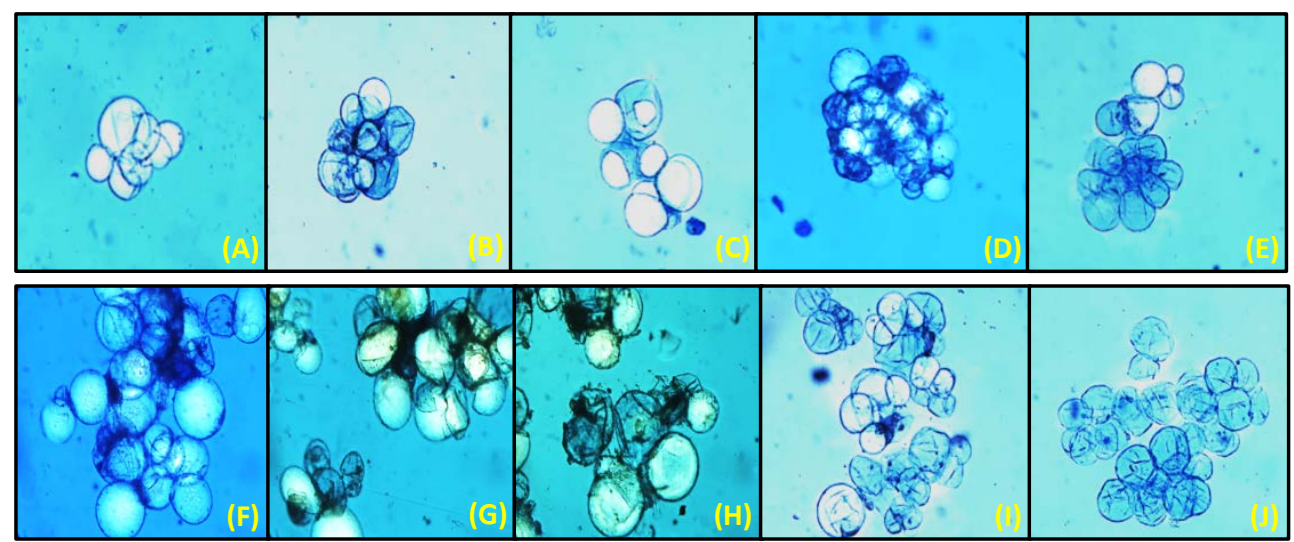

Figure 11. Evan's blue staining of suspension culture in Gamborg's B5 medium without any hormone, that are initiated from seed derived plant's callus showing live and dead cells by the time. (A) $3^{\text {rd }}$ day (B) $6^{\text {th }}$ day (C) $9^{\text {th }}$ day (D) $12^{\text {th }}$ day (E) $15^{\text {th }}$ day (F) $18^{\text {th }}$ day (G) $21^{\text {st }}$ day (H) $24^{\text {th }}$ day (I) $27^{\text {th }}$ day $(\mathrm{J}) 30^{\text {th }}$ day.

\section{Discussion}

In this study, we aimed to understand the growth pattern and behaviour of cells in suspension culture of Commiphora wightii. Plant cell growth in suspension culture can be determined and assessed by different methods like settled cell volume/packed cell volume, fresh weight and/or dry weight analysis, cell count/cell number [EVANS \& al. 2003]. Here we have used fresh weight and dry weight method to make a growth curve to understand different phases of cell growth over a period of time. A typical growth curve is a sigmoidal curve having distinct phases like the lag phase (Adaptive phase), the exponential phase (Growth phase) and the stationary phase [GEORGE \& al. 2008]. This study was done on two different mother plants and their growth was recorded in hormone $(0.5 \mathrm{mg} / \mathrm{l} 2,4-\mathrm{D})$ and hormone free medium. In tissue culture raised plants suspension culture showed a lag phase 
till $9^{\text {th }}$ day followed with exponential phase till $21^{\text {st }}$ day and then growth became steady with stationary phase in medium containing hormone. Whereas in medium without any hormone similar pattern has been seen but with less biomass produced. In seed raised plants suspension culture showed a different pattern with lag phase till $12^{\text {th }}$ day followed by exponential phase till $27^{\text {th }}$ day and then stationary phase was achieved in medium containing hormone. While in hormone free medium a gradual increase has been seen in growth of culture. After analysing the growth curve it can be suggested that sub - culturing of culture into fresh medium can be done in between $21^{\text {st }}$ day to $27^{\text {th }}$ day that is the end of exponential phase, which has been mentioned earlier in studies [STAFFORD \& WARREN, 1991]. For maintaining a fine cell suspension culture, it is necessary to sub - culture at regular interval else the medium became exhaust or cells may produce toxic substances [BHOJWANI \& RAZDAN, 1983]. In this study, it may be interesting to note that the growth of cell biomass in hormone free medium as quite comparable to that in case of hormone supplemented medium. KUMAR \& al. (2004), reported the formation of resin canals which are the main source of guggulsterone synthesis in nature, at torpedo and cotyledonary stage of somatic embryos. So converting non embryogenic callus into differentiated embryogenic callus would have more amounts of guggulsterones. As we showed in figure 1, callus converted into embryogenic green callus when cultured on hormone free medium. Similarly culturing in hormone free suspension medium would also be useful in producing more amounts of guggulsterones in vitro. Thus going to hormone free medium is better when the targeted end product is a nutraceutical product.

\section{Conclusions}

The cell growth under suspension state is higher in hormone supplemented medium (0.5 mg/l 2,4-D in Gamborg's B5 medium) compared to the hormone free B5 medium. Evan's blue staining also indicates higher number of living cells in hormone supplemented medium when compared to hormone free medium. This can possibly be due to a faster cell division rate in presence of hormone (2,4-D). However, the cell growth was clearly observed even without 2,4-D in hormone free medium. It was also observed that the growth rate peaks early in hormone supplemented medium compared to hormone free medium in general. Interestingly it was also observed that tissue culture raised explant material was marginally better as culture starter compared to mother plants growing in nature. The study clearly indicates that cell biomass bulked up without any hormone under suspension state is a viable way to produce cell biomass for production of guggul nutraceuticals in future. Work on augmenting secondary metabolite production in these cells holds the key on which work is under progress.

\section{Notes on contributors}

Shobha MEHRA, is a PhD Student at Genetics and Tree Improvement Division, Arid Forest Research Institute, Jodhpur, India. She is currently working on desert medicinal plant species of India.

Tarun KANT, is Scientist F and Head, Extension Division \& OIC, Information Technology at Arid Forest Research Institute, Jodhpur, India. The core area of his research work includes plant tissue culture, molecular genetics and functional genomics.

\section{Acknowledgment}

This study was financially supported by National Medicinal Plants Board (NMPB), New Delhi, India (Project No. R\&D/RAJ-04/2016-17). The author is grateful to the director, Arid Forest Research Institute, Jodhpur for providing laboratory facilities. 


\section{References}

AL-KHAYRI J. M. 2012. Determination of the date palm cell suspension growth curve, optimum plating efficiency, and influence of liquid medium on somatic embryogenesis. Emirates Journal of Food and Agriculture. 24(5): 444-455.

ARDESTANI N. K., SHARIFI M. \& BEHMANESH M. 2015. Establishment of callus and cell suspension culture of Scrophularia striata Boiss.: an in vitro approach for acteoside production. Cytotechnology. 67: 475485.

BARVE D. M. \& MEHTA A. R. 1993. Clonal propagation of mature elite trees of Commiphora wightii. Plant Cell, Tissue and Organ Culture. 35: 237-244.

BHARDWAJ M. \& ALIA A. 2019. Influence of growth hormone and additives on in vitro shoot initiation from apical and axillary meristems of Commiphora wightii. Journal of Drug Delivery and Therapeutics. 9(4s). 78-81. https://doi.org/10.22270/jddt.v9i4-s.3249

BHATIA A., TRIPATHI T., SINGH S., BISHT H., BEHL H. M., ROY R. \& SIDHU O. P. 2018. Comprehensive metabolite profiling in distinct chemotypes of Commiphora wightii. Natural Product Research. https://doi.org/10.1080/14786419.2018.1431629

BHOJWANI S. S. \& RAZDAN M. K. 1983. Plant tissue culture: theory and practice. Elsevier, Amsterdam. 46-47.

DASS S. \& RAMAWAT K. G. 2009. Elicitation of guggulsterone production in cell cultures of Commiphora wightii by plant gums. Plant Cell, Tissue and Organ Culture. 96: 349-353.

DENG R. 2007. Therapeutic effects of guggul and its constituent guggulsterone: cardiovascular benefits. Cardiovascular Drug Reviews. 25: 375-390.

EL ASHRY E. S., RASHED N., SALAMA O. M. \& SALEH A. 2003. Components, therapeutic value and uses of myrrh. Pharmazie. 58: 163-168.

EVANS D. E., COLEMAN J. O. D. \& KEARNS A. 2003. Plant Cell Culture. BIOS Scientific Publishers: London, UK. 169-172.

GEORGE E. F., HALL M. A. \& DE KLERK G. J. 2008. Stock plant physiological factors affecting growth and morphogenesis. In: GEORGE E. F., HALL M. A. \& DE KLERK G. J. (eds.). Plant Propagation by Tissue Culture. Springer: Dordrecht, The Netherlands: 403-422.

GUJRAL M. L., SAREEN K., TANGRI K. K., AMMA M. K. \& ROY A. K. 1960. Antiarthritic and antiinflammatory activity of gum guggul (Balsamodendron mukul Hook). Indian Journal of Physiology and Pharmacology. 4: 267-273.

JAIN A. \& GUPTA V. B. 2006. Chemistry and pharmacological profile of guggul - a review. Indian Journal of Traditional Knowledge. 5: 478-483.

KANT T., PRAJAPATI S. \& PARMAR A. 2010. Efficient micropropagation from cotyledonary node cultures of Commiphora wightii (Arn.) Bhandari, an endangered medicinally important desert plant. Journal of Plant Development. 17: 37-48.

KIMURA I., YOSHIKAWA M., KOBAYASHI S., SUGIHARA Y., SUZUKI M., OOMINAMI H., MURAKAMI T., MATSUDA H. \& DOIPHODE V. V. 2001. New triterpenes, myrrhanol A and myrrhanone A, from guggul gum resins, and their potent anti-inflammatory effect on adjuvant induced air-pouch granuloma of mice. Bioorganic and Medicinal Chemistry Letters. 11: 985-989.

KUMAR S., SURI S. S., SONIE K. C. \& RAMAWAT K. G. 2003. Establishment of embryonic cultures and somatic embryogenesis in callus culture of guggul - Commiphora wightii (Arn.) Bhandari. Indian Journal of Experimental Biology. 4: 69-77.

KUMAR S., SURI S. S., SONIE K. C. \& RAMAWAT K. G. 2004. Development of resin canals during somatic embryogenesis in callus culture of Commiphora wightii. Indian Journal of Biotechnology. 3: 267-270.

MAHESHWARI D. V. 2010. Guggul plantation shows good success in Kutch. Find Articles/Business/DNA: Daily News \& amp; Analysis; Mumbai/July 23.

MATHUR M., JAIN A. K. \& RAMAWAT K. G. 2007a. Optimization of guggulsterone production in callus cultures of Commiphora wightii (Arn.) Bhandari. Indian Journal of Biotechnology. 6: 525-531.

MATHUR M., JAIN A. K., DASS S. \& RAMAWAT K. G. 2007b. Guggulserone production in cell suspension cultures of Commiphora wightii grown in shake flask and bioreactors. Biotechnology Letters. 29: 979982.

MESELHY R. 2003. Inhibition of LPS-induced NO production by the oleo-gum resin of Commiphora wightii and its constituents. Phytochemistry. 62: 213-218.

PARMAR A. K. \& KANT T. 2012. Efficient micropropagation and evaluation of genetic fidelity of in vitro raised plants of Commiphora wightii Arn. (Bhandari). A medicinally important red listed species of arid regions. Journal of Plant Development. 19: 29-40. 
PARMAR A. K. \& KANT T. 2014. Efficient somatic embryogenesis and molecular marker based analysis as effective tools for conservation of red-listed plant Commiphora wightii. Journal of Bioscience and Biotechnology. 3(2): 169-182.

PATIL V. D., NAYAK U. R. \& DEV S. 1972. Chemistry of ayurvedic crude drugs I. Guggulu (Resin from Commiphora mukul-I: steroidal constituents. Tetrahedron. 28: 2341-2352.

PATIL V. D., NAYAK U. R. \& DEV S. 1973. Chemistry of Ayurvedic crude drugs III. Guggulu: long chain aliphatic tetrols, a new class of naturally occurring, lipids. Tetrahedron. 29: 1595-1598.

RAMULIFHO E., GOCHE T., VAN A. S. J., TSILO T. J., CHIVASA S. \& NGARA R. 2019. Establishment and characterization of callus and cell suspension cultures of selected Sorghum bicolor (L.) Moench varieties: a resource for gene discovery in plant stress biology. Agronomy. 9(5): 218. https://doi.org/10.3390/agronomy9050218

SATYAVATI G. V., DWARAKANATH C. \& TRIPATH S. N. 1969. Experimental studies on the hypocholesterolemic effect of Commiphora mukul Engl. (Guggul). Indian Journal of Medical Research. 57: 1950-1962.

SATYAVATI G. V. 1990. Use of plant drugs in Indian traditional systems of medicine and their relevance to primary health care. In: WAGNER H. \& FARNSWORTH N. R. eds. Economic and medicinal plant research. London: Academic Press. 4: 39-56.

SHISHODIA S., SETHI G., AHN K. \& AGGARWAL B. B. 2007. Guggulsterone inhibits tumor cell proliferation, induces S-phase arrest, and promotes apoptosis through activation of c-Jun N-terminal kinase, suppression of AKT pathway, and downregulation of antiapoptotic gene products. Biochemical Pharmacology. 74: 118-130.

SINGH N., GARG A., YADAV K. \& KUMARI S. 2010. Influence of growth regulators on the explants of Commiphora mukul (Hook. ex Stocks) Engl. under in vitro conditions. Researcher. 2: 41-48.

SONI V. 2010. Efficacy of in vitro tissue culture versus stem cuttings for propagation of Commiphora wightii in Rajasthan, India. Conservation Evidence. 7: 91-93.

STAFFORD A. \& WARREN G. 1991. Natural products and metabolites from plants and plants tissue culture. In: STAFFORD A. \& WARREN G. (eds). Plant Cell and Tissue Culture. Buckingham: Open University Press: $125-162$.

SUTHAR S. \& RAMAWAT K. G. 2010. Growth retardants stimulate guggulsterone production in the presence of fungal elicitor in fed-batch cultures of Commiphora wightii. Plant Biotechnology Reports. 4: 9-13.

TANWAR Y. S., MATHUR M. \& RAMAWAT K. G. 2007. Morphactin influence guggulsterone production in callus cultures of Commiphora wightii. Plant Growth Regulation. 51: 93-98.

URIZAR N. L. \& MOORE D. D. 2003. Gugulipid: a natural cholesterol lowering agent. Annual Review of Nutrition. 23: 303-313.

VED D., SAHA D., RAVIKUMAR K. \& HARIDASAN K. 2015. Commiphora wightii. The IUCN Red List of Threatened Species 2015: e.T31231A50131117. https://doi.org/10.2305/IUCN.UK. 2015-2.RLTS.T3 1231A50131117.en

VERMA N., SINGH S. K. \& GUPTA R. C. 1998. Simultaneous determination of the stereoisomers of guggulsterone in serum by high-performance liquid chromatography. Journal of Chromatography $B$ : Biomedical Sciences and Applications. 708: 243-248.

YADAV B. B. L., BILLORE K. V., JOSEPH J. G. \& CHATURVEDY D. D. 1999. Cultivation of Guggulu. Central Council for Research in Ayurveda and Siddha. New Delhi. India: 87 pp.

YUSUF A., RATHORE T. S. \& SHEKHAWAT N. S. 1999. Micropropagation of Commiphora wightii (Arn.) Bhandari - A threatened medicinal plant of semi-arid region. Indian Journal of Plant Genetic Resources. 12: 371-375.

ZHU N., RAFI M. \& DIPAOLA S. R. 2001. Bioactive constituents from gum guggul (Commiphora wightii). Phytochemistry. 56: 723-727.

\section{How to cite this article:}

MEHRA S. \& KANT T. 2020. Pharmaceutically active cell biomass growth pattern under cell suspension culture of Commiphora wightii - a critically endangered medicinal plant. J. Plant Develop. 27: 71-81. https://doi.org/10.33628/jpd.2020.27.1.71 